$7^{\circ}$ Simposio Internacional de Investigación Multidisciplinaria / Ciencia y Tecnología 7th Internationalm Symposium on Multidisciplinary Research / Sciences and Technology

\title{
CT-14 Parámetros fisicoquímicos para determinar la calidad del agua de la Laguna de Mecoacán, Paraíso, Tabasco
}

\author{
Physicochemical parameters to determine the water quality of \\ Mecoacan Lagoon, Paraíso, Tabasco \\ Ana L. Gómez-Calzada*, Carmen M. Flores-Guzmán, Ebelia A. Meraz, \\ Cristina Ponce-Parra, Jose L. Zapata-Haas
}

División Académica de Ingeniería y Arquitectura, Universidad Juárez Autónoma de Tabasco, México.

*Autor al que se dirige la correspondencia: analuisa682016@hotmail.com

\section{Resumen}

耳 $\mathrm{n}$ esta investigación se estudiaron los parámetros fisicoquímicos del agua de la laguna Mecoacán de Paraíso - Tabasco, tomando en cuenta cinco zonas de muestreos con repetición de tres muestras por zona en toda la Laguna, teniendo un total de 30 muestras, con el fin de conocer el estado actual de la calidad del agua y tomar medidas correctivas, en caso de ser necesario su tratamiento. Los análisis que se realizaron de acuerdo a las Normas Oficiales Mexicana (NOM) son: Sólidos totals (ST) ppm, Grasas y aceites (ppm), Dureza total (ppm), pH, Sólidos sedimentables (SS) (ppm), Solidos suspendidos totales (SST) ppm, Sustancias activas al azul de metileno (SAAM)

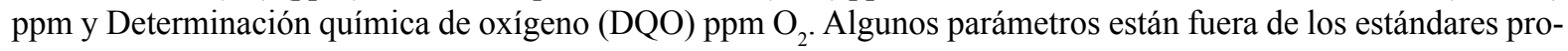
vocando daño a la flora, fauna y habitantes que viven dentro y cerca de la laguna.

Palabras claves: Contaminación, calidad, lagunas, parámetros

\begin{abstract}
Tn this research we studied the physicochemical parameters of the water of the Mecoacan lagoon from Paraíso 1 Tabasco, taking into account five areas of sampling with three repetitions per area in the lagoon, with a total of 30 samples, in order to know the current state of the quality of the water and take corrective action, if necessary for any treatment. Analysis carried out according to the official Mexican standards (NOM) are: Total solids (TS) ppm, fats and oils (ppm), total hardness (ppm), pH, sedimentable solids (SS) (ppm), total suspended solids (TSS) ppm, active substances (SAAM) ppm and methylene blue chemical determination of oxygen (COD) ppm $\mathrm{O}_{2}$. Some parameters were out of standards, causing damage tom flora, fauna and inhabitants living in and around the lagoon.
\end{abstract}

Keywords: Pollution, quality, lagoons, parameter 